\title{
Enriched Bread Preparation of Fiber Flour from Passiflora edulis (Purple Passion Fruit)
}

\author{
Lauren Menegon de Oliveira ${ }^{1 *}$, Andressa Jantzen da Silva Lucas², Maria Eduarda G Zacalhuk3, Debora \\ Beatriz S Gomes ${ }^{3}$ and Natalia Cristina Dalmago ${ }^{3}$
}

${ }^{1}$ Laboratório de Tecnologia de Alimentos, Faculdade de Tecnologia de Sinop (FASTECH), Brazil

${ }^{2}$ Laboratório de Tecnologia de Alimentos, Universidade Federal do Rio Grande (FURG), Brazil

${ }^{3}$ Laboratório de Tecnologia de Alimentos, Escola Técnica Estadual de Sinop (SECITEC), Brazil

\section{Introduction}

The genus Passiflora brings together about 400 species of passion fruit, most originally from the Neotropics (America), with about 120 native to Brazil [1]. The species of greatest commercial interest in the country are $P$. edulis and P. alata [2].

The purple passion fruit ( $P$. edulis) can be consumed in juice or as fresh fruit. Its fruits are globose with 4 to $5 \mathrm{~cm}$ in diameter. The bark is green before ripening, becoming purple after initiated the process [2].

The processing of fruit for juice production generates considerable amount of by-products such as passion fruit peel, orange peel and apple pomace [3]. The use of these secondary materials fruit processing as ingredients in the food formulation, and reduce waste and prevent environmental contamination by improper disposal of these materials may facilitate access of low income to functional foods [4].

Several studies indicate the presence of polyphenols [5], polyunsaturated fatty acids [6] and fibers [7], among other classes of substances and the presence of these substances in the fruit passion fruit may indicate potential as a functional food.

A food can be considered functional if it is shown that it can affect beneficially one or more target functions in the body, and have adequate nutritional effects, in a manner that is both relevant to the well being and health and for reducing the risk of a disease [8]. Drugs are not considered, because the principles responsible for the beneficial effects are not taken from food [9].

The fibers derived from fruits exhibit technological advantages over the cereal fibers, widely used to enrich foods. These advantages occur due to increased soluble fiber content, the higher retention capacity for water and fat, the lower phytic acid content and less caloric value [10]. It is assumed thus far in the nutritional as technological point of view, the important applicability of these by-products in the food industry as an alternative to conventional fibers.

The physiological and metabolic effects of the adequate intake of dietary fiber in the prevention of many chronic degenerative diseases are well established in the scientific community [11]. However, their intake by the Brazilian population was below the recommended level, probably due to the replacement of natural food, fiber sources, processed foods and nutritionally poor [12].

The importance of this theme is demonstrated by the fact promote the use of parts of the food with the potential nutritional value that are usually not used and can add value to waste, as the passion fruit peel, and several preventive health campaigns have demonstrated the need to supply the insufficient intake of dietary fiber, motivating the industry to develop foods enriched with fiber, adding nutritional value to their products, as well as contribute to the promotion of population health [13]. Thus, it is important that new ingredients and formulations are studied in order to expand this food segment, serving always the sensory attributes demanded by the consumer.

\section{Material and Methods}

For the preparation of flour, it was purchased in the local market of Sinop-MT municipality of passion fruit. The passion fruits were washed in tap water, allowed to soak in solution of concentration 100 ppm of chlorine for 15 minutes and again washed under running water. After peeling they were separated and the albedo of the pulp

\footnotetext{
*Corresponding author: Dr. Lauren Menegon, Laboratorio de Tecnologia de Alimentos, Faculdade de Tecnologia de Sinop (FASTECH), Sinop, MT, Brazil

Accepted: September 28, 2019

Published online: September 30, 2019

Citation: de Oliveira LM, Lucas AJS, Zacalhuk MEG, et al. (2019) Enriched Bread Preparation of Fiber Flour from Passiflora edulis (Purple Passion Fruit). J Hum Nutr 3(1):72-74
} 
Table 1: Formulations of different concentrations developed in the bread.

\begin{tabular}{|l|l|l|}
\hline Ingredients & standard bread & \\
\hline & $\mathbf{0 \%}$ & $\mathbf{1 0 \%}$ \\
\hline Wheat Flour (g) & 300 & 270 \\
\hline passion fruit peel flour (g) & - & 30 \\
\hline Sodium chloride (g) & 6 & 6 \\
\hline Sucrose (g) & 15 & 15 \\
\hline Fresh Yeast (g) & 9 & 9 \\
\hline Ascorbic acid (g) & 0.027 & 0.027 \\
\hline Vegetable fat & 6 & 6 \\
\hline Water (mL) & 180 & 180 \\
\hline
\end{tabular}

Table 2: Shows the results of the chemical composition of the standard bread and bread enriched with $10 \%$ passion fruit shell flour.

\begin{tabular}{|l|l|l|}
\hline & Standard bread & Bread 10\% \\
\hline Energy value (kcal) & $358^{\mathrm{a}} \pm 0.16$ & $326^{\mathrm{b}} \pm 0.12$ \\
\hline Carbohydrates (\%) & $75.44^{\mathrm{a}} \pm 0.47$ & $68.91^{\mathrm{b}} \pm 0.32$ \\
\hline Protein (\%) & $9.69^{\mathrm{a}} \pm 0.47$ & $9.02^{\mathrm{a}} \pm 0.21$ \\
\hline Lipids (\%) & $6.13^{\mathrm{a}} \pm 0.38$ & $6.24^{\mathrm{a}} \pm 0.19$ \\
\hline Fibers (\%) & $3.04^{\mathrm{a}} \pm 0.02$ & $8.49^{\mathrm{b}} \pm 0.11$ \\
\hline Ash (\%) & $5.70^{\mathrm{a}} \pm 0.11$ & $7.34^{\mathrm{b}} \pm 0.24$ \\
\hline
\end{tabular}

(*) Equal letters on the lines do not differ statistically $(p<0.05)$.

and minced into small pieces which were taken to the greenhouse at $55{ }^{\circ} \mathrm{C}$ until completely dry (approximately 30 hours). Samples were ground in an industrial blender, sieved and stored in plastic pots with lids and the dark at room temperature until the moment of use. The straight dough method was used for the preparation of bread.

The formulation (Table 1 ) with $10 \%$ passion fruit shell flour was evaluated ( $10 \%$ flour basis) and compared with the standard bread to verify the influence on the technological characteristics, fiber content and sensory quality.

First, the dry ingredients were homogenized. Subsequently the added vegetable fat, water and dissolved yeast. The mixture was kneaded to develop the gluten.

The dough was divided into 3 pieces of $160 \mathrm{~g}$ and was subsequently rounded and shaped into spherical shape by roller manually. After this process was set up in metallic molds previously oiled and taken to fermentation in an oven at $30^{\circ} \mathrm{C}$ for $60 \mathrm{~min}$, with controlled temperature and relative humidity. The bread was forneado at $200{ }^{\circ} \mathrm{C}$ for 30 $\mathrm{min}$ in an electric oven, preheated for $10 \mathrm{~min}$.

The total nitrogen content was determined by the method of paragraph [14], the crude protein content obtained by using factor of 6.25 for nitrogen conversion into protein. The ash content determined according to AACC (1995) [14]. The lipid content as determined according to [15] in a Soxhlet type extractor using petroleum ether as solvent. Quantification of crude fiber was determined by the crude fiber [16]. Carbohydrates were calculated by the difference of the other components. The energy value was calculated using the following Atwater conversion factors: Carbohydrate $4 \mathrm{kcal} / \mathrm{g}$, Protein 4 kcal/g, Lipids $9 \mathrm{kcal} / \mathrm{g}$ [17].

\section{Results and Discussion}

It is possible to observe according to Table 2 , the enriched bread and passion fruit shell flour increased by $179.28 \%$ fiber content compared to standard bread making the formulations proposed in this study meet the expectations of consumers who appreciate the product and that strive for nutritional quality of their meals, whose physical and chemical properties (such as increased viscosity of the intestinal content and high degree of fermentability) are closely related to most of the beneficial effects of dietary fiber in the human body. These effects are control of postprandial blood glucose and decreases in serum cholesterol as well as increasing the microbiótico balance and the production of fatty acids short chain, resulting from the fermentation of fiber and essential for maintaining intestinal health [18]. It should be emphasized that the contribution of soluble fiber in the foodstuff cannot be observed with such intensity when using the conventional fibers from cereals, because these are composed (almost entirely) from the insoluble fraction [10].

Perez, et al. [19] used eggplant flour and Mauro, et al. [20] added flours obtained from cabbage and spinach stems to increase the value of farinaceous food fibers and had a significant increase in the levels of dietary fiber and moisture content of the formulations test compared to the standard formulation demonstrating the high hydrophilicity of dietary fiber, which proved to be directly related to your content in food.

Some authors evaluated the composition of biscuits made with passion fruit peel flour in terms of crude fiber. Santana, et al. [21] found $4.27 \%$ crude fiber when added passion fruit shell flour and tapioca starch in place of wheat flour in cookie formulations. Ishimoto, et al. [22] that with added passion fruit peel flour the crude fiber content was found to be $3.24 \%$. Lower values $(2.96 \%, 3.15 \%)$ were found by Santos, et al. [23].

The presence of high dietary fiber content of breads promotes water retention in the product after cooking, which may be related to hydration capacity of fiber property which profoundly influences the final product texture [3].

The addition of passion fruit peel flour in food promotes beneficial health effects due to the presence of dietary fiber. Some authors have devoted efforts to prove the benefits promoted by flour health passion fruit peel. Janebro, et al. [24] observed that the use of passion fruit peel flour in the diet of patients with diabetes has been effective in controlling blood glucose, lower triglycerides and increase HDL cholesterol. The patients ingested $30 \mathrm{~g}$ of flour for a period of 60 days.

Miranda, et al. [25] found that the intake of 30 grams of 
passion fruit shell flour for 60 days caused a significant decrease in glucose levels and improvement in the lipid profile in addition there was a reduction in total cholesterol levels. The authors evaluated the patients into three sessions: Time zero, after 30 days and after 60 days.

\section{Conclusion}

Enriched bread with passion fruit peel flour had higher fiber content when compared to standard bread, so it can be concluded that the use of passion fruit peel in the manufacture of flour for bread production is an alternative to avoid the disposal of this waste by producers of juices and enrich many foodstuffs nutritionally.

\section{References}

1. Bernacci LC, Vitta FA, Bakker YV (2003) Passifloraceae. In: Wanderley MGL, Shepperd GJ, Melhem TS, Flora Fanerogâmica do Estado de São Paulo. RiMa/FAPESP, São Paulo, 3: 247-274.

2. Ruggiero C (1987) Cultura do maracujazeiro. Ribeirão Preto: Legis Summa.

3. Bortoluzzi RC (2009) Aplicação de fibra obtida da polpa da laranja na elaboração de mortadela de frango. Faculdade de Ciências Farmacêuticas, Universidade de São Paulo, São Paulo.

4. Canteri MHG, Moreno L, Wosiacki G, et al. (2012) Pectina: da matéria-prima ao produto final. Polímeros, 22: 149-157.

5. Zeraik ML, Yariwake JH (2010) Quantification of isoorientin and total flavonoids in Passiflora edulis fruit pulp by HPLC-UV/DAD. Microchem J 96: 86-91.

6. Kobori CN, Jorge N (2005) Caracterização dos óleos de algumas sementes de frutas como aproveitamento de resíduos industriais. Cien Agrotec 29: 1008-1014.

7. Córdova KRV, Gama TMMTB, Winter CMG, et al. (2005) Características físico-químicas da casca do maracujá amarelo (Passiflora edulis flavicarpa Degener) obtida por secagem. Bol Cent Pesq Proc Alim 23: 221-230.

8. Roberfroid MB (2002) Functional food concept and its application to prebiotics. Digest Liver Dis 34: 105-110.

9. Costa AM, Tupinambá DD (2005) O maracujá e suas propriedades medicinais estado de arte. Faleiro FG, Junqueira NTV, Braga MF, Maracujá: Germoplasma e melhoramento genético. Embrapa Cerrados, Planaltina, 20: 475-506.

10. Larrauri JA (1999) New approaches in the preparation of high dietary fibre powders from fruit by-products. Trends in Food Science \& Technology 10: 3-8.

11. Gonçalves MCR, Costa MJC, Asciutti LSR, et al. (2007) Fibras dietéticas solúveis e suas funções nas dislipidemias. Rev Bras Nutri Clín 22: 167-173.

12. Menezes EW, Giuntini EB, Lajolo FM (2000) Perfil da ingestão de fibra alimentar e amido resistente pela população brasileira nas últimas três décadas. In: Lajolo FM, Saura-Calixto F, Witting de Penna E, Menezes EW, org. Fibra dietética en Iberoamérica: tecnología y salud: obtención, caracterización, efecto fisiológico y aplicación en alimentos. São Paulo: Varela 1: 165-178.

13. Cerqueira PM, Freitas MCJ, Pumar M, et al. (2008) Efeito da farinha de semente de abóbora (Curcubita maxima, L.) sobre o metabolismo glicídico e lipídico em ratos. Revista de Nutrição 21: 129-136.

14. (1995) American Association of Cereal Chemists. Approved methods. ( $9^{\text {th }}$ edn) Saint Paul.

15. (1995) Association of Official Analytical Chemists - AOAC. Official methods of analysis. (16 ${ }^{\text {th }}$ edn) Washington, 2.

16. BRASIL (1991) Portaria 108 de 04 de setembro de 1991. Normas gerais de amostragem para análise de rotina. Método número 11 - Fibra Bruta. Diário Oficial [República Federal do Brasil], Brasília, 19813, 17 set, Seção 1.

17. MENDEZ MH (1995) Tabela de Composição de Alimentos. Niterói: Editora da Universidade Federal Fluminense 41.

18. Rique ABR, Soares EA, Meirelles CM (2002) Nutrição e exercício na prevenção e controledas doenças cardiovasculares. Revista Brasileira de Medicina do Esporte 8: 244-254.

19. Lajolo FM, Saura- Perez PMP, Germani R (2007) Elaboração de biscoitos tipo salgado, com alto teor de fi bra alimentar, utilizando farinha de berinjela (Solanum melongena, L.). Ciência e Tecnologia de Alimentos, 27: 186-192.

20. Mauro AK, Silva VLM, Freitas MCJ (2010) Caracterização física, química e sensorial de cookies confeccionados com farinha de talo de couve (FTC) e farinha de talo de espinafre (FTE) ricas em fibra alimentar. Ciência e Tecnologia de Alimentos 30: 719-728.

21. FC Santana, JV Silva, AR Alves, et al. (2011) Desenvolvimento de biscoito rico em fibras elaborado por substituição parcial da farinha de trigo por farinha da casca do maracujá amarelo (Passiflora Edulis flavicarpa) e fécula de mandioca (Manihot Esculenta crantz). Alimentos e Nutrição 22: 391-399.

22. Fábio Yuitiro Ishimoto, Adilson Issamu Harada, Ivanise Guilherme Branco, et al. (2007) Aproveitamento Alternativo da Casca do Maracujá-Amarelo (Passiflora edulis f. var. flavicarpa Deg.) para Produção de Biscoitos. Revista Ciências Exatas e Naturais 9.

23. Aline Alves Oliveira Santos, Alécia Josefa Alves Oliveira Santos, Aline Rezende Alves, et al. (2011) Elaboração de biscoitos a partir da incorporação de produtos da mandioca e casca de maracujá (Passiflora edulis Flavicarpa) na farinha de trigo. Scientia Plena, 7: 1-7.

24. Janebro DI (2008) Efeito da farinha da casca do maracujá-amarelo (Passiflora edulis f. flavicarpa Deg.) nos níveis glicêmicos e lipídicos de pacientes diabéticos tipo 2. Revista Brasileira de Farmacologia 18: 724-732.

25. Oliveira Marcos Rodrigo, Miranda Gilson Silva, Rennó Luciana Navajas, et al. (2014) Efeito do consumo da aveia e farinha da casca de maracujá sobre a glicemia e lipemia em um grupo de voluntários. Revista de Ciência Farmacêuticas 35: 245-250.

DOI: $10.36959 / 487 / 285$

Copyright: (C) 2019 de Oliveira LM, et al. This is an open-access article distributed under the terms of the Creative Commons Attribution License, which permits unrestricted use, distribution, and reproduction in any medium, provided the original author and source are credited. 